\title{
Not Just Giving: How Do Companies Play?
}

\author{
Ruth A. Shapiro
}

In Asia, many companies have been quietly addressing local problems through a familiar model: that of family patronage. The deep cultural roots of family influence have taken Asian development along a different path than that taken in the United States and Europe, despite certain parallels in their economic growth.

Family influence matters greatly in Asian economies, though not every nation is identical. Some markets have developed within democratic systems and some under authoritarian regimes. Certain governments have erected barriers to foreign investment, while others have embraced international capital. Some countries have advanced economies, with the GDPs of Japan, South Korea, and Singapore among the highest in the world. Some remain poor, while others such as China, India, and Indonesia are an unusual mix, having created vast wealth and a rising middle class, yet retaining a significant populace living on less than $\$ 2$ per day.

Despite this variation, there are important cultural characteristics shared across the region. One of the most important is the value of families in the overall economic systems.

The notion of a company itself as family forms an intrinsic part of Asian economic life. In this model, the owner/CEO treats workers as extended family, particularly in companies in which the family plays a dominant role.

\footnotetext{
R.A. Shapiro

CAPS, Hong Kong SAR, China
}

(C) The Author(s) 2018

R.A. Shapiro et al., Pragmatic Philanthropy, https://doi.org/10.1007/978-981-10-7119-5_7 
Today, Asian companies typically have more professional employees, yet family remains an important driver of corporate decisions, including how a company relates to its surrounding community.

In fact, according to a $2013 \mathrm{KPMG}$ study, a significant percentage of companies in many Asian countries with market capitalization of more than US\$50 million remain family dominated. The chart below shows how prevalent family control is in Asia.

India: $67 \%$

Philippines: $66 \%$

Thailand: $66 \%$

Singapore: $63 \%$

Malaysia: $62 \%$

Indonesia: $61 \%$

Hong Kong: 62\%

South Korea: $58 \%$

Japan, China, and to some degree Taiwan, are countries where familydominant firms are not in the majority, but still even in these countries, there are family-controlled firms that are important mainstays.

For those not as familiar with this phenomenon, it can be difficult to convey how integrated families are in all aspects of business life. I recall once bringing a famous American business guru to meet with a group of Asian business leaders. His talk wasn't going well, and I called for a coffee break to talk to him about changing gears and moving to a new topic. He said he knew exactly what to do and strode off confidently to restart the session. "Let me now address something that everyone cares deeply about," he said. "Work-life balance..."-I cannot begin to explain what a dud that comment was! Work-life balance is not an issue in Asia the way it is in the West. Work is life and one's friends are also one's business partners. Families are involved in business in their daily lives, affecting with whom they dine and, absolutely, whom they trust. This is true when making business decisions, and it is very much the case when making philanthropic decisions. The borders between these different worlds, much more delineated in the West, are often blurred and overlapping in Asia.

Family control is important to understand when looking at a company's corporate social responsibility (CSR) programs and the focus of its philanthropy. It is quite common for a family to route its philanthropy through the company rather than create a separate personal foundation. I have had numerous conversations with ultra-high-net-worth individuals 
who automatically consider their philanthropy through the company instead of setting up a separate family foundation. The company and the family remain tightly linked in many Asian economies.

A 2011 UBS/Insead report on Asian philanthropy says, "One has to be cognizant of the fact that in Asia it is hard to establish degrees of separation between family philanthropy and company philanthropy/CSR. Often what is seen as individual or family giving is "company giving" now practiced through the establishment of company foundations and trusts."

When a family is in charge, there tend to be certain common practices. First, the philanthropy is very much aligned with the personal interests and connections of the patriarch. This is slowly starting to change as the second and third generations go to foreign business schools and return home with new ideas about CSR, including the notion of impact investing and social enterprise support-topics we will explore in greater depth later in Chapter 8. A second typical practice is to run the company foundation under a member of the family, usually a wife, daughter, or niece. This person represents the family and allows the chairman to have any final say. In Asia, despite divisions by sex in many business practices, it is culturally acceptable to have a female family member lead philanthropic efforts. There are many examples. In India, Nita Ambani, wife of multi-billionaire Mukesh Ambani, runs the Reliance Foundation, the philanthropic arm of the Reliance Corporation. In China, the Wahaha Charitable Foundation is run by Kelly Fuli Zong, daughter of founder and chairman Zong Qinghou. The Lopez Group Foundation in the Philippines is run by 11 family members, with Mercedes Lopez Vargas as the president.

In a company dominated by a family, the patriarch often still plays the critical role. This dual persona of chief executive and father figure will likely remain in place in Asia because it adheres to norms that work within many Asian societies. The fuzzy distinction between family and company reflects the larger context of the fundamental use and appreciation of relationships. As Li and Redding write, "Across the board, Asian economies are rich in interpersonal trust, as expressed in extensive networks of reciprocal relationships between individuals both inside the firm and outside." Asian societies do tend to build stronger interpersonal networks than their Western counterparts, both inside the family and with friends, leveraging them for business. ${ }^{2}$ It stands to reason that if personal relationships play a major role in business, they would be at least as important in situations in which there is no clear bottom line, like philanthropy.

Even in countries where the family/corporation lines have become clearer such as Japan and Taiwan, we can see a greater comfort level with the 
company acting in a patriarchal fashion. In Asia, especially Japan, company towns are thriving. In a company town, the company provides many of the social services such as schools, elder care, sports, and recreational activities, and while the term has become anathema in the West, company towns are thriving in Asia. Positions in towns like Toyota City are eagerly sought. There is a comfort level with the company taking on the role of avuncular benefactor that does not have an equivalent in most Western societies.

Company towns are even increasing in Asia, while they decline in Europe and America. In January 2011, The Economist wrote, "What is dying in the West is surviving or being reborn in the emerging world. New company towns are being constructed from nothing ... and old ones are being given a new lease of life." 3

One of the most notable company towns is Jamshedpur, the home of Tata Steel. Established in the early twentieth century, Tata Steel and its affiliate companies provide housing, health care, schools, utilities, and sporting fields and equipment. In an interview in 2016, Ratan Tata, former chairman of the Tata Group, explained how his appreciation for interconnectivity between the company and its employees was forged during his visits to Jamshedpur early in his tenure with the group.

Understanding the role of companies in Asian philanthropy requires seeing the pivotal role that families still play in Asian companies, the related acceptance of patriarchal tendencies, and also the degree to which interpersonal relationships are cultivated and valued. The notions of family and community are integral to many companies in Asia.

Given the oligarchic nature of many Asian markets, it is easy to appreciate the critical role that companies can play in delivering social goods to their communities. Within the last few years, virtually all companies have become expected to pursue philanthropic activities, and while some are slow to engage in a significant manner, many have embraced their roles as benefactors, with senior managers and family members devoting considerable time to their programs.

Companies employ different approaches when taking on a role in social delivery. This chapter describes eight:
1. Corporate Philanthropy
2. Volunteerism
3. Shared Value
4. Social Business
5. DIY
6. Funding a Corporate Need 


\section{Alliances}

8. Longer-term Partnerships

Many companies in Asia use several of these strategies at the same time, but they are distinct and each worthy of explanation and illustration. They also have unique applications within Asia. While the strategies described are employed by firms around the world, those in the region have developed them in culturally appropriate ways.

\section{Corporate Philanthropy}

The first and most prevalent technique is direct funding of local nonprofit organizations. Corporate philanthropy has been on the rise for a decade and continues to grow, despite some economic hard times. In 2012, 66 percent of all charitable giving in China came from corporations, according to the Conference Board. India also sees substantial corporate support for CSR, especially after new legislation requiring top companies to direct 2 percent of after-tax income to certified CSR activities. According to finance minister Arun Jaitley in a March 2016 Economic Times article, companies spent Rs 8347 crore (more than US\$1.2 billion) in the previous year.

Our case studies illustrate how much corporate philanthropy means to many SDOs in Asia. Bainian Vocational Services, which offers vocational training to migrant and rural teens, gets 51 percent of its budget from local Chinese and multinational corporations. Mercy Malaysia receives 45 percent of its funding from companies. The Magic Bus in India receives 51 percent of its funding from corporations. (In other chapters, we have discussed how most SDOs in Asia do not have the capacity to keep accurate records, maintain transparency and evaluate impact. In all 30 case studies, we asked for the percentage of overall donations that come from corporations; only five were able to answer the question specifically, although most acknowledged the importance of corporate support to their overall budget.)

With traditional corporate philanthropy, a company supports nonprofit organizations in areas determined by management. In Asia, that is often education, the most popular area for funding across all countries. In any case, the company responds to a proposal or identifies SDOs with which it wants to work. Participation typically involves a simple transfer of funds. Relationships between the company and the SDO may go on for years when designed as a partnership, with the company providing financial resources and the SDO carrying out a program approved by the company. 
Western companies tend to work in this fashion as well. They identify a need they want to address and then find the SDO partner that has the capability and experience to deliver that good. For the SDO, corporate support can be a tremendous boon.

Oftentimes, however, the relationship between the two entities encounters difficulties. Companies and SDOs might have different approaches and necessarily have different aims. In a 1999 book Corporate-NGO Partnership in Asia-Pacific, editor Tadashi Yamamoto writes of the numerous challenges that face ongoing corporate-NGO partnerships. During our work, we have found two innovative programs that seek to address these challenges and improve the relationships between companies and SDOs. CCPHI is an Indonesian nonprofit that promotes partnerships among companies, NGOs, and local governments to encourage sustainable communities. CCPHI acts as a sort of marriage counselor to the corporate-SDO partners. Every relationship needs a third party from time to time. CCPHI acts as that third party, offering training, counseling, and tools for effective and sustainable corporate-SDO partnerships.

Singapore Management University (SMU) has also developed a program to address the disconnect that often occurs between companies, SDOs, and the government. In the new Master of Tri-Sector Collaboration degree program now offered, students learn skills to traverse the barriers between these three parts of society. Center Director Martin Tan says, "As societal issues in the world become more complex, we need to recognize that there isn't a one-size-fits-all approach to solving these issues nor will there be one single entity that will have all the answers. Not the government, businesses, or civil society on its own. However, we could if we collaborate across all sectors and leverage on each other's strengths and expertise to address some of society's greatest challenges collectively." This course, now in its second year, is the only one of its kind in the world.

Both SMU's program and CCPHI offer innovative means to bring about more effective partnerships. Both recognize that the need to work together to solve complex problems, while still relatively untested in Asia, will be critical going forward.

\section{Volunteerism}

Another tactic embraced by many Asian companies is volunteerism. A popular activity is arranging a specific day when employees are encouraged to clean a park, build a house, or teach a workshop. Many times, employees are encouraged to raise funds themselves, which are matched by the 
company. While these activities do not bring about systemic change, they do solve a targeted problem and give the employees a sense of pride and shared values with their employer. Li \& Fung, based in Hong Kong, provides a good example of such volunteerism, along with other kinds of philanthropy. The Li \& Fung team in Pakistan has identified a girls' school that receives financial support from both Li \& Fung employees and management. The employees have offered workshops there on hygiene and public speaking to help the girls feel more empowered.

\section{Shared Value}

Companies also engage with the community through shared value initiatives. Shared value, a term coined by Michael Porter and Mark Kramer in 2011 , refers to a strategy whereby companies bring economic value to themselves while addressing a social need. In their seminal article introducing this concept, they wrote, "Not all profit is equal... Profits involving a social purpose represent a higher form of capitalism, one that creates a positive cycle of company and community prosperity."

While there has been much talk and excitement about shared value in Asia, there are few examples of Asian companies successfully carrying it out. One of the more notable cases of this work is Manila Water in the Philippines. Manila Water figured out how to decrease siphoning and protect the pipeline so that clean, cheaper water reached those in the poorest districts of Manila. This successful project improved water access for the poor while at the same time increasing Manila Water's bottom line. Jaime Zobel de Ayala, chairman and CEO of the Ayala Group, the holding company that includes Manila Water, has said, "Meeting social needs should be embedded in our business models and should be undertaken using the same disciplines as those of business."

Another example of shared value is Kirin Beverage Company's Hyoketsu Wanashi pear juice. Kirin developed the product using pears from the Fukushima region as a way to support local farmers after the earthquake and tsunami that devastated that region. In addition to supporting the community, Hyoketsu Wanashi has been a great commercial success.

Not surprisingly, shared value is an appealing concept. Shared value does not entail corporate philanthropy but can solve a social problem and generate profit at the same time, aligning incentives and buttressing programmatic sustainability. When the company and the community prosper, the initiatives are more sustainable over time. At this stage, shared value initiatives are new globally and very new in Asia. We can expect to see much more innovation from work of this kind in the years to come. 


\section{Social Business}

In some ways, the opposite approach to shared value is the notion of "social businesses." This term, coined by Nobel Laureate Muhammad Yunus in his 2010 seminal book Building Social Business, designates companies choosing to forego profits in order to conduct a business that brings significant social benefits. Yunus has created several of these in Bangladesh, including one with clothing maker Uniqlo. In this social business, Grameen Uniqlo has established manufacturing plants employing local workers, to create a less-expensive line of clothing sold locally, at cost. In collaboration with Yunus and the Grameen Foundation, several companies have created social businesses in Bangladesh, including Veolia Water, Danone, and Intel.

Though these are wonderful initiatives, it is not clear that large companies would choose to forego profits if not for the involvement of an acclaimed Nobel prize winner. Partnering with Mohammad Yunus entails additional benefits for multinational companies as they garner high-profile approval from the public. Some companies in Asia have taken a different approach by creating social enterprises that, unlike social businesses, are independent of the larger firm. These will be discussed in greater detail in Chapter 8.

\section{DIY}

The fourth strategy for community engagement is direct delivery of a social good, when companies arrange to do the work on their own. Those that do this believe, often with some justification, that they have the skills to deliver a social good more efficiently than by working through an NGO.

SM Holdings in the Philippines did just this with its BDO Foundation for building clinics and schools in the typhoon-ravaged areas of Leyte and Samar. The Federation of Filipino Chinese Chamber of Commerce and Industry Inc. followed a similar route, building 6000 schools throughout the Philippines. The Reliance Foundation also develops its own intervention strategies and carries out work through its own initiatives in rural development, health, and education. 
In China, Lenovo has put in place the Lenovo Youth Public Entrepreneurship program, a company effort to transfer skills from Lenovo employees to startup social entrepreneurs. Lenovo employees help provide training, venture capital, and instruction in public speaking and other skills so that young college students interested in careers in public entrepreneurship can have a greater chance of success.

\section{Funding a Corporate Need}

A fifth, related strategy is to offer services that companies themselves need. This is primarily done in education and training. Many companies find that they cannot find the talent they require, so they have created training programs to promote the necessary skills in current and future employees.

Skill training is not limited to Asian companies, of course. It takes place globally, and in emerging economies around the world, it is often a fundamental part of employment. It can be helpful to the employee and the company, but it does not address the larger societal problems of poor schools and an unprepared workforce. In interviews, a number of executives expressed interest in developing more comprehensive schemes to create win-win-win outcomes: employee, company, and society at large.

\section{Alliances}

In some cases, corporations and corporate leaders find it useful to develop an alliance or consortium to bring about change. Recognizing that the Philippines needed coordinated responses to typhoons, Jaime Zobel de Ayala of the Ayala Group and Manny Pangilinan of PLDT created the Philippine Disaster Recovery Foundation, which is building a disaster operations center to manage private sector efforts for relief. In China, corporate leaders have come together to create the SEE Foundation to address environmental issues and the Ai You Foundation to provide medical aid to children. In Malaysia, under the leadership of Yayasan Hasanah, the philanthropic arm of the nation's sovereign wealth fund, the Yayasan Amir program finds corporate sponsors for schools that have adopted the Yayasan Hasanah curriculum. Alliances like these can leverage and coordinate resources and donations in ways that do-it-alone strategies cannot. 


\section{Longer-term Partnerships}

The last way to engage is the one that we believe has the greatest potential in Asia, a hybrid of the outreach strategies described earlier. Many companies blend a variety of skills with a longer term, venture capital approach. They place the skills that make companies successful alongside financial resources to build the capacity of SDO partners to bring about sustainable change.

SDOs may be nonprofits, but they need to think more like businesses. To maximize their impact, they should be concerned with transparent accounting, financial forecasting, strategic planning, organizational management and development, and a whole host of other skills that have traditionally been labeled as business skills. These skills are in ample supply within the private sector.

While illustrative examples of this type of partnership are not yet in great supply, there are some pointing the way forward. Here are three examples in India, Malaysia, and Thailand.

Dilasa Sanstha has been working with farming communities in India for 20 years, with the goal of increasing production and stabilizing livelihoods. Several years ago, Dilasa entered into a strategic partnership with the Axis Bank Foundation. ABF helped Dilasa set up funding to expand rural credit. It also assisted Dilasa with its internal budgeting and accounting system, and it supported the creation of a monitoring and evaluation system. With ABF's help, for the first time, Dilasa could collect critical impact data on beneficiary income, household assets, migration level, education levels, diet, investment plans, and insurance policies. The partnership with ABF enabled Dilasa to operate at a much larger scale and to help a great many more farmers and rural communities.

Another example of this kind comes from Malaysia. Mercy Malaysia began with a small group of doctors who wanted to provide relief from natural disasters. But they found it difficult to create the systems necessary for nimble and effective response to unforeseen events, so they partnered with Khazanah Berhad, the sovereign wealth fund. Khazanah helped Mercy develop management systems to efficiently deploy people and resources to a disaster zone. The partnership has helped Mercy become a serious and internationally acclaimed provider of disaster assistance around the world. Dato Sri Azman Mokhtar, CEO of Khazanah, said that its work 
will help broaden Mercy Malaysia's impact by strengthening its service delivery, governance, and financial sustainability.

In Thailand, Siam Commercial Bank has partnered with the Songkhla Forum, a nonprofit organization based in the southern Songkhla province. In 2012, Siam Commercial Bank revamped its CSR program and decided to focus its attention on youth-related services. It also decided that rather than just providing financial support, it would enter into a longer-term partnership with a youth-related SDO to help it became more strategic, better managed, and better governed. Songkhla Forum, with its services for at-risk youth, was a natural match. In addition to management support and financial assistance, the bank has provided help with finance and accounting, HR management, data management, and strategic development.

In all of these three cases, the companies provided financial resources and technical resources. They committed to the SDOs for the longer term, developing the trust and the relationships necessary to make the partnerships really work. These models point the way to an exciting new trend, of the deployment of business skills for social good.

Although the strategies may differ, the change in corporate attitude is clear. Moved by consistent public expectations for doing good, companies realize they must engage with their communities; the only question is how. Throughout the region, Asian firms are on the front lines of creating innovative community engagement strategies, to be long-term stakeholders in the region's continued growth. Companies designed on the longstanding family model often find this a natural transition.

Asian companies are not the only ones testing the boundaries of company involvement; exciting new trends and innovation are taking place around the world. What is true in Asia, however, is that much of the innovation stems from long-held values and practices. Families remain important, and the role of the family in company decision-making is critical. As we saw in the do-it-yourself strategies of Reliance and SM Holdings, in Li \& Fung's community outreach, and with the Wahaha company foundation in China, family-led CSR programs are not only the norm but exemplify company-community engagement. Families desire to be around for the long term. They have the control to look beyond quarterly reporting and to take a longer-term view that creates value for them and the communities in which they operate. 


\section{Notes}

1. UBS INSEAD Study on Family Philanthropy. p. 23. http://sites.insead. edu/social_entrepreneurship/documents/insead_study_family_philantropy_asia.pdf. Accessed August 20, 2014.

2. Li, Peter Ping and Gordon Redding. "Social Capital in Asia: Its Dual Nature and Function." In The Oxford Handbook of Asian Business Systems. Ed. Michael Witt and Gordon Redding. Oxford University Press, Oxford, UK, 2014, pp. 313-333.

3. https://www.economist.com/blogs/schumpeter/2011/01/company_ towns. Accessed January 11, 2017.

Open Access This chapter is licensed under the terms of the Creative Commons Attribution 4.0 International License (http://creativecommons.org/licenses/ by $/ 4.0 /$ ), which permits use, sharing, adaptation, distribution, and reproduction in any medium or format, as long as you give appropriate credit to the original author(s) and the source, provide a link to the Creative Commons license and indicate if changes were made.

The images or other third party material in this chapter are included in the chapter's Creative Commons license, unless indicated otherwise in a credit line to the material. If material is not included in the chapter's Creative Commons license and your intended use is not permitted by statutory regulation or exceeds the permitted use, you will need to obtain permission directly from the copyright holder.

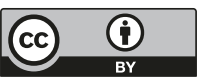

